\title{
FUNGSI PENGAWASAN OLEH INSPEKTORAT PENGAWASAN DAERAH BERBASIS PENGADUAN MASYARAKAT DALAM PERSPEKTIF HUKUM PROGRESIF
}

\author{
Dian Trisusilowaty ${ }^{1}$, Anggita Doramia Lumbanraja2*, Suteki² \\ 1Program Studi Magister IImu Hukum, Fakultas Hukum, Universitas Diponegoro \\ 2Fakultas Hukum, Universitas Diponegoro \\ anggitalumbanraja@live.undip.ac.id
}

\begin{abstract}
The Inspectorate of Region Police (Itwasda) has a function as the internal supervision in Police Region and also has a function to receive Public complaints, whether as information, complaints, dissatisfaction, irregularities acts in the performance of Police Region in order to give legal settlement and legal certainty. This study examines the function of preventive supervision of Itwasda through public complaints with the perspective of the Progressive Law, by using the of socio-legal research with qualitative analysis. The driving factors of supervision implementation: the existence of good coordination between the function units, the structural hierarchy of the absolute level, and community support for the existence of the Itwasda. Obstacle factors of the implementation of the supervisory function: the limited authority of the Itwasda, acceptance of public complaints that are not one gate, imbalance in the number of supervisory resources, supervision of peers and a lack of public understanding of the complaints mechanism. The concept of the supervisory function offered is to be more able to prevent undisciplined of police members, there needs to be a one-door public complaints mechanism, the merger of investigators from several function units, computerization of complaints and the need for special Criminal Law Procedure for Law Officials.
\end{abstract}

Keywords: Itwasda; Public Complaints; Progressive Law.

\section{ABSTRAK}

Inspektorat Pengawasan Daerah (Itwasda) bertugas melakukan pengawasan internal di lingkungan Kepolisian Daerah dan juga bertugas menerima aduan masyarakat yakni dalam bentuk informasi, keluhan, ketidakpuasan dan atau penyimpangan atas kinerja Kepolisian Daerah guna mendapatkan penyelesaian dan kepastian hukum. Penelitian ini mengkaji perspektif Hukum Progresif mengenai fungsi pengawasan preventif oleh Inspektorat Pengawasan Daerah melalui aduan masyarakat di lingkungan Kepolisian Daerah, menggunakan metode penekatan penelitian socio-legal dengan analisa kualitatif. Faktor pendorong pelaksaanaan pengawasan: adanya koordinasi dan kerjasama yang baik antar satuan fungsi, Struktrual Kepolisian berjenjang yang bersifat mutlak, dan dukungan masyarakat terhadap keberadaan Itwasda. Faktor penghambat pelaksanaan fungsi pengawasan adanya kewenangan Itwasda yang terbatas, penerimaan aduan masyarakat yang tidak satu pintu, tidak seimbangnya jumlah sumber daya pengawas, pengawasan terhadap rekan sejawat dan kurangnya pemahaman masyarakat terhadap mekanisme pengaduan. Konsep fungsi pengawasan yang ditawarkan agar lebih mampu mencegah tindakan indisipliner anggota kepolisian berbasis aduan masyarakat yaitu, perlu adanya mekanisme pengaduan masyarakat satu pintu, penggabungan penyidik dari beberapa satuan fungsi, komputerisasi pengaduan dan perlu ada Hukum Acara Pidana khusus bagi Aparat Penegak Hukum.

\section{Kata Kunci: Itwasda; Pengaduan Masyarakat; Hukum Progresif.}

\footnotetext{
* Corresponding Author
} 


\section{A. PENDAHULUAN}

Polisi dalam menjalankan tugasnya sebagai penegak hukum, bukan hanya harus tunduk pada hukum yang berlaku sebagai aspek luar (eksternal). Polisi dibekali pula dengan etika kepolisian sebagai aspek dalam (internal) kepolisian. Etika kepolisian adalah norma tentang perilaku polisi untuk dijadikan pedoman dalam mewujudkan pelaksanaan tugas yang baik bagi penegakan hukum, ketertiban umum dan keamanan masyarakat (Kunarto, 1997). Etika kepolisian menjadi sangat penting dikarenakan aspek ini sangat menentukan peforma seorang polisi dalam melaksanakan tugasnya sebagai seorang penegak hukum.

Etika kepolisian sepatutnya juga ditunjang dengan pengawasan yang baik demi mencegah pelanggaran-pelanggaran kode etik yang dilakukan oleh Polisi, sehingga pada akhirnya menimbukan kerugian pada masyarakat. Pengawasan tersebut dapat berupa pengawasan terhadap penyalahgunaan wewenang dan pelanggaran. Hal ini berperan dalam memelihara keamanan dan ketertiban masyarakat, menegakkan hukum,serta memberikan perlindungan, pengayoman, dan pelayanan kepada masyarakat dalam rangka terpeliharanya keamanan dalam negeri yang dilakukan oleh Kepolisian Negara Republik Indonesia secara berjenjang. Dikarenakan pengawasan kepolisian dilakukan secara berjenjang, maka dari segi hubungan kewenangannya,
Pengawasan Kepolisian ada yang bersifat vertikal dan horizontal (Sadjjono, 2006).

Pengawasan vertikal adalah pengawasan yang dilakukan oleh instansi/organisasi atasan terhadap instansi/organisasi yang berdasarakan hirarki posisinya lebih rendah. Sedangkan pengawasan horizontal adalah pengawasan yang dilakukan oleh lembaga atau bidang lain yang berada di level atau tingkatan hirarki yang sama (Sadjijono, 2006). Berdasarkan Pasal 7 Perpres No. 5 Tahun 2017 tentang Susunan Organisasi dan Tata Kerja Kepolisian Negara Republik Indonesia yang mengatur eksistensi pengawas di lingkungan Polri (Tingkat Mabes), yakni Inspektorat Pengawasan Umum (Itwasum) yang berada di bawah Kapolri. Sedangkan untuk lingkungan Polda, unsur Pengawasan diemban oleh Inspektorat Pengawasan Daerah (Itwasda) berdasarkan Pasal 1 Perpol Nomor 14 Tahun 2018 Tentang Susunan Organisasi Dan Tata Kerja Kepolisian Daerah. Oleh karena itu Itwasda mengemban tugas dan wewenang pengawasan pada setiap bidang di lingkungan Polda secara struktural dan pada satuan tingkat wilayah secara fungsional. Itwasda berada di bawah Kapolda.

Secara umum, pelanggaran yang sering dilakukan oleh Polisi di Indonesia adalah banyaknya Polisi yang masih menggunakan kekerasan untuk mendapatkan pengakuan atau keterangan dari tersangka dalam penyidikan. Bentuk kekerasan yang dilakukan oleh penyidik adalah kekerasan fisik, psikis, 
Law Reform

Volume 15, Nomor 1, Tahun 2019
Program Studi Magister Ilmu Hukum Fakultas Hukum Universitas Diponegoro maupun hukum. Contoh lain dari pelanggaran oleh oknum anggota Polri secara umum adalah adanya pungutan liar yaitu dengan memberikan sanksi denda secara sepihak bagi pengendara yang melanggar lalu lintas. Bahkan Polisi juga rentan dengan praktik korupsi dikarenakan kewenangan hukum polisi dalam menindak anggota masyarakat (alat kontrol sosial) dapat menciptakan celah-celah kesempatan bagi oknum Polisi dalam melakukan tindakan korupsi (Rahardjo, 2002).

Pelanggaran-pelanggaran yang dilakukan oleh anggota Polri ini sesungguhnya dapat diminimalisir dengan adanya pengaduan oleh masyarakat mengenai pelanggaran-pelanggaran yang telah dilakukan. Berdasarkan Peraturan Kapolri (PERKAP) No. 2 Tahun 2012 tentang Tata Cara Penanganan Pengaduan Masyarakat (Dumas) di lingkungan Polri, dalam hal penanganan pengaduan masyarakat di lingkungan Polda dilaksanakan oleh Itwasda Polda tersebut. Pengaduan masyarakat meliputi penyalahgunaan wewenang dan atau pelanggaran disiplin yang dilakukan oleh anggota Polri. Berdasarkan Perkap Dumas, Itwasda juga bertugas untuk memproses dan merespon Dumas. Sehingga dalam hal Dumas ini, Itwasda memegang peranan yang besar dan penting dalam memberikan solusi dan kepastian hukum bagi masyarakat yang merasa dirugikan oleh tindakan interdisipliner dari oknum anggota Polda.
Penanganan pengaduan masyarakat dilaksanakan untuk mewujudkan penyelenggaraan negara yang bebas dari korupsi, kolusi dan nepotisme serta meningkatkan pelayanan Polri yang profesional, modern dan terpercaya dibutuhkan peran serta masyarakat dalam bentuk penyampaian pengaduan sesuai dengan prinsip keterbukaan untuk ditangani secara baik, cepat, tepat, dan dapat dipertanggungjawabkan.

Penerimaan pengaduan masyarakat dalam rangka mencegah tindakan indisipliner anggota Polda termasuk dalam suatu hal yang progresif. Di mana dengan adanya penanganan pengaduan masyarakat diharapkan penegakan hukum oleh anggota Polri membawa manfaat yang besar bagi masyarakat. Menurut Satjipto Rahardjo (Rahardjo, 2005), Kebutuhan akan hukum progresif dengan pendekatan yang komprehensif dan multidisipliner merupakan kata kunci untuk memahami asumsi yang ada di balik hukum progresif itu sendiri. Paling tidak ada beberapa asumsi yang perlu diperhatikan dalam hukum progresif. Pertama, Hukum adalah untuk manusia, bukan sebaliknya. Kehadiran hukum bukan untuk dirinya sendiri, melainkan untuk sesuatu yang lebih luas dan besar. Kalau terjadi permasalahan di bidang hukum, maka hukum harus ditinjau dan diperbaiki, bukan manusia yang dipaksa untuk dimasukkan ke dalam skema hukum. Kedua, Hukum bukan institusi yang mutlak dan final, melainkan dalam proses untuk terus menjadi. Hukum progresif 
Law Reform

Volume 15, Nomor 1, Tahun 2019
Program Studi Magister Ilmu Hukum Fakultas Hukum Universitas Diponegoro harus memiliki landasan nilai yang tidak terjebak ke dalam semangat legal formal semata, namun memihak kepada semangat kemanusiaan (spirit of humanity) (Mustansyr, 2008).

Ada beberapa penelitian sebelumnya yang meneliti tentang pengawasan internal kepolisian dan ada pula penelitian yang telah membahas mengenai pengawasan perilaku anggota Polri berbasis pengaduan masyarakat. Pada penelitian dalam kajian kriminologi yang dilakukan oleh Widiawati (Widiawati, 2011) yang mengkaji tentang pencatatan pengaduan masyarakat tentang penyimpangan Polri dengan Konsep FADO (using unnecessary Force, Abusing their Authority, Speaking Discourteously, using Offensive Language) yang dikemukakan oleh Seron, et al (Seron, Pereira, \& Kovath, 2004). Widiawati memfokuskan kajian pada pengaduan masyarakat yang diterima oleh Divpropam dan Kompolnas. Menurut Widiawati pencatatan pengaduan masyarakat masih memiliki kelemahan dan tidak akurat yakni kendala dalam mengkategorisasikan jenis penyimpangan sehingga pengaduan tentang penyimpangan polisi yang diterima tidak mampu dicatat secara spesifik dan menyeluruh, sementara prosedur kategorisasi dalam pencatatan yang spesifik sangat diperlukan dalam penyelenggaraan fungsi pengawasan.

Pada penelitian yang dilakukan oleh Hassel dan Archbold (Hassel \& Archbold, 2013) dtemukan bahwa tingkat produktivitas anggota kepolisian menentukan besar kecilnya jumlah pengaduan masyarakat terhadap dirinya, artinya semakin banyak kasus yang ditanganinya maka semakin meningkat pula jumlah keluhan maupun pengaduan terhadapnya. Hal ini selaras dengan pendapat Brandl, et al (Brandl, Stroshine, \& Frank, 2001) dan Lerch's, et al (Lersch \& Mieczkowski, 1996) yang berpendapat bahwa pengaduan masyarakat muncul seiring dan berhubungan dengan tingginya aktivitas penegakan hukum yang dilakukan oleh aparat kepolisian.

Selain penelitian berkenaan dengan pengkategorisasian Dumas dan hubungan jumlah pengaduan dengan produktivitas anggota polisi, ada juga penelitian yang dilakukan oleh Kabib Nawawi (Nawawi, 2010) untuk mengoptimalisasikan profesionalisme polisi maka perlu dilakukan reformasi birokrasi Polri di dalam lingkungan internal lembaga kepolisian. Hal ini menjadi penting dikarenakan kinerja polisi bersentuhan langsung dengan masyarakat. Kurang sempurnanya proses reformasi di tubuh Polri menyebabkan hukum tidak dijalankan secara bermakna oleh anggota Polri. Dari aspek progesifitas, polisi hanya berpikir menjalankan undang-undang secara primitif dan belum bisa mengimplementasikannya dengan baik.

Serangkaian penelitian-penelitian terdahulu mengenai pengawasan internal terhadap kepolisian, pengaduan masyarakat, dan profesionalisme kepolisian dalam kacamata progresifitas, belum ada 
Law Reform

Volume 15, Nomor 1, Tahun 2019
Program Studi Magister Ilmu Hukum Fakultas Hukum Universitas Diponegoro satu pun penelitian yang membahas mengenai fungsi pengawasan yang dilakukan oleh Inspektorat Pengawasan Daerah dalam hal Pengaduan Masyarakat yang dikaji menurut Hukum Progresif. Pembahasan mengenai ini menjadi perlu dan sangat penting, dikarenakan Kepolisian Daerah merupakan satuan pelaksana utama yang strategis dan bersentuhan langsung dengan tindak pidana atau pelanggaran yang terjadi di wilayahnya yakni di wilayah Provinsi. Anggota Polda dalam tugasnya lebih sering bersentuhan langsung dengan masyarakat yang ada di wilayahnya, hal ini berbeda dengan Mabes Polri yang wilayah wewenangnya dalam cakupan nasional. Belum ada penelitian yang membahas tentang bagaimana pengaduan masyarakat terhadap kinerja anggota Polda tersebut dilihat dari Hukum Progresif.

Peneltian ini mengkaji Fungsi Pengawasan oleh Inspektorat Pengawasan Daerah Berbasis Pengaduan Masyarakat dalam Perspektif Hukum

Progresif. Perspektif ini diperlukan agar diperoleh gambaran yang lebih komprehensif dan menyeluruh agar memenuhi nilai keadilan, kepastian hokum dan kemanfaatan yang dibutuhkan oleh masyarakat.

Penelitian ini mengkaji pelaksanaan fungsi pengawasan oleh Inspektorat Pengawasan Daerah (Itwasda) apakah telah mampu untuk mencegah tindakan indisipliner anggota kepolisian di wilayah Polda dan menawarkan konsep pengawasan Itwasda dalam mencegah dan menindak tindakan anggota Polri di lingkungan Polda

\section{B. METODE PENELITIAN}

Metode penelitian yang digunakan oleh Peneliti adalah metode penelitian empiris yang mengkaji fakta-fakta tentang fungsi pengawasan Itwasda Polda Jawa Tengah dalam rangka mencegah tindakan indisipliner anggota kepolisian berbasis aduan masyarakat dalam prespektif hukum progresif dengan Socio-Legal. Metode analisa data digunakan analisa kualitatif yang lebih menekankan pada proses penyimpulan dedukatif dan induktif serta pada dinamika hubungan antar fenomena yang diamati dengan menggunakan logika ilmiah (Syamsudin, 2007).

Pada artikel ini, penelitian difokuskan di lingkungan Polda Jawa Tengah. Alasan mengapa Penulis memilih Polda Jawa Tengah sebagai objek penelitian dikarenakan sekitar tahun 2014 terjadi 638 kasus pelanggaran yang dilakukan oleh anggota Polda Jawa Tengah baik pelanggaran disiplin, pelanggaran kode etik maupun kasus pidana (Kencana, 2015), hingga di tahun 2018 masih ada kasus pelanggaran yang bermuara pada Pemberhentian Tidak Dengan Hormat (PTDH) 15 orang anggota Polda Jawa Tengah (Kumoro, 2018). Sebagai salah satu Polda Tipe A, maka peran dan fungsi Itwasda dan Bidang Profesi dan Pengamanan (Propam) memegang peranan penting yakni dalam 
Law Reform

Volume 15, Nomor 1, Tahun 2019
Program Studi Magister Ilmu Hukum Fakultas Hukum Universitas Diponegoro hal mensterilkan Polda Jawa Tengah dari perilaku anggota Polda yang melanggar, sehingga perlu ditelaah lebih lanjut upaya mengoptimalisasi fungsi pengawasan Itwasda yang dapat membersihkan organisasi Polda Jawa Tengah dari tindakan-tindakan interdisipliner yang dilakukan oleh anggotanya.

\section{HASIL DAN PEMBAHASAN}

\section{Pelaksanaan Fungsi Pengawasan Itwasda Polda terhadap Tindakan Anggota Polda}

Berdasarkan Peraturan Kepala Kepolisian Negara Republik Indonesia (Perkap) Nomor 2 Tahun 2013 Tentang Penyelenggaraan Sistem Pengendalian Intern Pemerintah di Lingkungan Kepolisian Negara Republik Indonesia. Itwasda merupakan salah satu Aparat Pengawasan Intern Pemerintah (APIP) yang mempunyai tugas pokok dan fungsi pengawasan di lingkungan Polda, yakni melakukan pengawasan intern atas penyelenggaraan tugas dan fungsi, serta akuntabilitas keuangan negara di Lingkungan Polda, yakni melalui proses audit, reviu, evaluasi, pemantauan dan kegiatan pengawasan lain.

Berdasarkan Perpol SOTK Polda, Itwasda membawahi 1 Inspektorat Bidang (Itbid) dan 2 subbagian, yakni Subbagian Perencanaan dan Administrasi (Subbagrenmin) dan Subbagian Pengaduan Masyarakat, Analisis dan Evaluasi serta Penguatan Pengawasan (Subbagdumasanwas). Yang bertindak melakukan pengawasan di dalam organisasi Itwasda adalah Itbid dibantu oleh Subbagdumasanwas. Itibid bertugas menyelenggarakan pengawasan di lingkungan Polda. Sedangkan Subbagdumasanwas bertugas menjadi fasilitator pelaksanaan kegiatan fungsi pengawasan, menganalisis dan mengevaluasi hasil pengawasan, mengelola kegiatan di lingkungan Polda dalam menekan budaya anti korupsi dan menangani pengaduan masyarakat. Melalui salah satu tugas Subbagdumasanwas yakni menangani pengaduan masyarakat (Dumas), maka Itwasda termasuk salah satu organisasi dalam lingkungan Polda yang masuk dalam Satker Dumas, hal ini berdasarkan Perpol No. 2 Tahun 2012 tentang Tata Cara Penanganan Pengaduan Masyarakat di Lingkungan Polri.

Dumas merupakan bentuk penerapan dari pengawasan masyarakat yang disampaikan oleh masyarakat, instansi pemerintah atau pihak lain kepada Polri berupa sumbangan pikiran, saran gagasan atau keluhan/pengaduan yang bersifat membangun. Dumas tersebut digolongkan atau dikelompokkan menjadi dua tipe, yakni dumas yang disampaikan secara langsung dan dumas yang disampaikan secara tidak langsung. Itwasda sebagai salah satu organisasi dalam Satker atau Sentra Pelayanan Dumas berperan dalam menindaklanjuti Dumas yang diterima secara tidak langsung oleh Polda. Namun apabila Dumas ditangani secara langsung, Itwasda tidak lagi berperan disini, melainkan langsung ditindak lanjuti oleh personel 
Law Reform

Volume 15, Nomor 1, Tahun 2019
Program Studi Magister Ilmu Hukum Fakultas Hukum Universitas Diponegoro yang menerima pengaduan dan wajib diteruskan kepada pimpinan dan/atau Sentra Pelayanan Dumas untuk diproses lebih lanjut. Dumas yang dapat disampaikan antara lain terkait dengan Pelayanan Polda, Penyimpangan Perilaku Pegawai Negeri dan penyalahgunaan wewenang. Mengenai kasus tindakan interdisipliner yang dilakukan oleh anggota Polda dapat dilaporkan dikarenakan merupakan salah satu bentuk dari Penyimpangan Perilaku dan/atau Penyalahgunaan wewenang, tergantung dari bentuk tindakan interdisipliner yang dilakukan oleh oknum tersebut. Berdasarkan Perpol Nomo 14 Tahun 2011 Tentang Kode Etik Profesi Polri (KEPP), sebuah penyimpangan perilaku atau penyalahgunaan wewenang yang telah dilaporkan dapat ditindaklanjuti dan dapat digolongkan menjadi tindak pidana atau pelanggaran etik. Penggolongan tindakan interdisipliner anggota tersebut penting terkait dengan jenis penanganan yang harus digunakan.

Itwasda pada pokoknya bukan merupakan bagian yang mengkaji materi dari dumas yang diadukan oleh pelapor, namun bagian yang memonitor keseluruhan proses dumas. Itwasda bertanggung jawab untuk mengoordinasi seluruh Dumas yang diterima dan ditangani di tingkat Polda. Dalam penanganan Dumas, Itwasda diberikan kewenangan untuk berkoordinasi dengan kementerian/lembaga/badan/komisi dan masyarakat atau organisasi kemasyarakatan. Sebagai koordinator, Itwasda diberikan kewenangan untuk menilai dan menetapkan klasifikasi dan pengodean dumas, meminta keterangan dan/atau dokumen asli/fotokopi dari fungsi Reserse Kriminal atau Profesi dan Pengamanan yang menangani dumas, memeriksa dan meneliti dokumen satfung yang menangani dumas, menerima dan menindaklanjuti dumas, membuat surat pemberitahuan tindak lanjut dan perkembangan penanganan dumas kepada pelapor; membuat kertas kerja klarifikasi dumas pada saat asistensi, dan membuat laporan hasil penanganan dumas.

Pembuatan laporan dumas, Itwasda mengelompokkan status dumas menjadi tiga kategori, yakni status proses $(\mathrm{P})$, selesai benar (SB) atau selesai tidak benar (STB). Status proses (P) diberikan kepada dumas yang masih dalam proses penanganan. Status selesai benar (SB) diberikan kepada dumas yang telah selesai dilakukan klarifikasi dan dapat dibuktikan kebenarannya, sementara status selesai tidak benar (SB) diberikan kepada dumas yang telah selesai dilakukan klarifikasi dan tidak dapat dibuktikan kebenarannya.

Tindakan indisipliner anggota yang berkaitan dengan tindak pidana, hukum acara yang digunakan adalah hukum acara pidana sebagaimana yang digunakan untuk masyarakat umum. Tidak ada pembedaan hukum acara meskipun polisi merupakan aparat penegak hukum yang memiliki peran penting dalam penegakan hukum. Hukum acara pidana yang berlaku adalah hukum acara pidana sebagaimana 
diatur dalam Undang-Undang No. 8 Tahun 1981 tentang Hukum acara Pidana (KUHAP). Anggota yang diadukan akan mengalami proses yang sama dengan proses yang dilakukan terhadap masyarakat hukum, yakni Penyelidikan, Penyidikan, Penuntutan dan Proses Pengadilan.

Tindakan indisipliner anggota yang berkaitan dengan pelanggaran kode etik profesi, yang menangani adalah Bidpropam. Hal ini sebagaimana diatur di dalam Perpol KEPP

Secara garis besar dapat disimpulkan bahwasanya Itwasda mampu untuk melaksanakan tugas dan fungsinya dalam rangka pengawasan terhadap tindakan anggota. Itwasda yang memiliki peran sebagai koordinator dari segala penanganan dumas, telah menjalankan perannya dengan baik, meskipun terdapat masalah utamanya terhadap jangka waktu penyelesaian dumas yang tergolong tidak menentu dan lama. Namun hal tersebut dapat dimaklumi terutama apabila tindakan indisipliner yang dilakukan anggota diduga merupakan tindak pidana, yang mana dalam pemrosesannya menggunakan hukum acara pidana yang berlaku untuk masyarakat umum-yang jangka waktunya tidak menentu.

\section{Faktor Pendukung dan Penghambat Fungsi Pengawasan Itwasda terhadap Tindakan Anggota}

Penelitian ini melaksanakan observasi maupun wawancara dengan Irwasda dan Kasubbag Dumasan terkait dengan fungsi pengawasan tindakan anggota yang dilakukan oleh Itwasda. Faktor yang mempengaruhi pelaksanaan fungsi pengawasan dibagi menjadi dua, yakni faktor pendorong dan faktor penghambat.

Faktor pendukung pelaksanaan fungsi pengawasan Itwasda terhadap tindakan anggota memiliki beberapa faktor pendorong pelaksanaan fungsi pengawasan Itwasda terhadap tindakan yang dilakukan oleh anggota Polda. Faktor-faktor tersebut terdiri dari faktor yang membuat Itwasda mampu melaksanakan kewenangannya, dan faktor yang membantu Itwasda dalam pelaksanaan fungsinya. Faktor-faktor tersebut antara lain, Yang Pertama, Koordinasi/kerjasama yang baik antar satuan fungsi. Sebagaimana telah dijelaskan, pelaksanaan fungsi pengawasan di lingkungan Polda tidak hanya dilakukan oleh Itwasda. Terdapat satuan fungsi lain yang berperan dalam pelaksanaan fungsi perngawasan tersebut, utamanya dari Direktorat Reserse Kriminal Umum (Ditreskrimum), Direktorat Reserse Kriminal Khusus (Ditreskrimsus), Direktorat Reserse Narkoba (Diresnarkoba), dan Bidang Profesi dan Pengamanan (Bidpropam) dalam lingkungan Polda. Koordinasi yang dilakukan oleh satuan fungsi terkait dengan Itwasda berjalan baik, sehingga tidak terdapat penghambatan proses penanganan dumas yang terjadi dikarenakan miskomunikasi antar satuan fungsi. Yang Kedua, Struktrual Polri yang berjenjang. Dengan struktur Polri yang berjenjang dan bersifat 
Law Reform

Volume 15, Nomor 1, Tahun 2019
Program Studi Magister Ilmu Hukum Fakultas Hukum Universitas Diponegoro mutlak akan lebih memudahkan untuk melakukan penanganan dumasan atau pengawasan lainnya karena untuk pelaporan perkembangan hasil klarifikasi dapat dilaporkan secara berjenjang. Sebagai contoh : hasil klarifikasi diwilayah yang dilakukan subbagdumasan akan dilaporkan ke Irwasda selaku pimpinan Itwasda yang kemudian prosesnya mendapat tindak lanjut dari satfung yang berwenang. Proses ini akan diawasi langsung oleh Irwasda yang kemudian akan diteruskan ke unsur pimpinan yaitu Wakil Kepala Kepolisian Daerah Jawa Tengah serta pucuk pimpinan paling tinggi di wilayah hukum Polda Jawa Tengah yaitu Kepala Kepolisian Daerah Jawa Tengah, khususnya mengenai pengaduan yang bersifat atensi/urgent. Yang Ketiga, Dukungan masyarakat. Dengan Masyarakat menyambut positif keberadaan Itwasda sebagai pengawas internal Polda. Dukungan tersebut-yang berupa dumas kepada Itwasda—membantu Itwasda dalam penanganan tindakan-tindakan anggota yang tidak sesuai dengan peraturan perundang-undangan dan KEPP.

Faktor penghambat pelaksanaan fungsi pengawasan Itwasda terhadap tindakan Anggota. Kebanyakan faktor penghambat disebabkan oleh sistem yang digunakan dalam penanganan dumas. Meskipun demikian, terdapat faktor-faktor eksternal yang turut menghambat pelaksanaan fungsi Itwasda terhadap tindakan anggota Polri khususnya dalam lingkungan Polda. Faktor Pertama adalah
Kewenangan Itwasda yang terbatas. Itwasda dalam pelaksananaan fungsi pengawasan tindakan anggota Polri hanya sebatas mengumpulkan keterangan apakah benar terjadi pelanggaran atau tidak, yang kemudian akan diserahkan kepada satuan fungsi yang berwenang dan tidak sampai pada kewenangan mengadili dan kewenangan menindak. Kewenangan Itwasda hanya dalam mengkoordinir dan memonitor proses penanganan dumas.

Faktor Kedua, Mekanisme yang tidak satu pintu. Penerimaan dumas dilakukan bukan hanya oleh Itwasda, namun juga dilakukan oleh satuan fungsi yang lain. Selain itu, penanganan dumas atas tindakan anggota baik merupakan tindak pidana maupun pelanggaran KEPP, dilakukan oleh sub bagian lain dari orgasisasi Polda, sehingga dalam pengontorolan mengalami sedikit kesulitan. Hal ini berkaitan dengan pengawasan penanganan suatu aduan. Itwasda seringkali harus menanyakan atau melakukan pengecekan kembali sudah sejauh mana penanganan pengaduan tersebut kepada satfung lain yang menjadi tempat teradu. Hal ini tentu saja membutuhkan waktu dan terdapat kemungkinan misscommunication dalam proses penanganan yang seperti itu. Waktu terlalu banyak terbuang terutama untuk koordinasi. Selain itu dumas yang masuk seringkali berulang, artinya laporan dumasan tidak hanya masuk ke Itwasda namun juga ke Bidpropam dimana apabila tidak dilakukan pengecekan dengan 
teliti akan memperoleh jawaban dumas yang berbeda.

Faktor yang Ketiga, yakni tidak imbangnya rasio jumlah anggota subbagdumasan dibandingkan keseluruhan tugas yang diemban. Jika dilihat hanya dari fungsi pengawasan terhadap anggota berdasarkan dumas, anggota subbag lebih dari cukup untuk melaksanakannya, terutama dikarenakan dalam fungsi tersebut, Itwasda tidak lebih berfungsi sebagai tukang foto yang sifatnya deskriptif, dan bukan mesin utama yang menjatuhkan sanksi terhadap dumas tersebut. Namun demikian, jika dilihat dari keseluruhan fungsi dan kewenangan yang diemban serta jumlah pengaduan masyarakat yang masuk baik ditingkat Polda maupun dari Polres yaitu 35 (tiga puluh lima) Polres, Itwasda seringkali keteteran karena jumlah anggota yang kurang dibandingkan dengan beban kerja. Hal ini juga berkaitan dengan proses penanganan dumas dimana harus melakukan pemeriksaan dan klarifikasi ke satker wilayah yang diadukan sedangkan itwasda juga masih harus melakukan tugas pengawasan lain seperti wasrik tahap 1 dan 2, LKIP, verifikasi, dsb. Sehingga dapat disimpulkan bahwa Itwasda masih kekurangan personil.

Faktor yang Keempat, yakni mengenai Penanganan terhadap Rekan Sejawat. Sebagaimana yang dialami oleh pengawas-pengawas internal yang lain, melakukan pengawasan dan penindakan terhadap rekan sejawat lebih sulit dibandingkan dengan penindakan eksternal. Penanganan rekan sejawat lebih sulit dikarenakan yang ditindak/diawasi dan yang mengawasi berada dalam satu organisasi yang sama. Implikasinya akibat pengawasan tersebut berdampak pada kinerja.

Faktor penghambat yang Kelima yaitu perihal Masyarakat yang kurang paham dengan mekanisme. Seringkali masyarakat melakukan pengaduan bukan kepada bagian yang berwenang misalnya media umum sehingga pengaduan belum ditndak lanjuti secara tepat namun telah ramai diberitakan padahal pengaduan tersebut belum berarti benar. Disisi lain masyarakat belum memahami tentang apa yang dilaporkan dan bagaimana bukti-bukti yang dapat disertakan, sehingga terdapat aduan yang tidak tahu kemana surat perkembangan penanganan dumas dapat diberikan contoh pengaduan dengan tidak menyebutkan identitas atau surat kaleng. Selain itu, masyarakat tidak berani untuk melakukan pengaduan dikarenakan stigma bahwasanya aduan yang mereka laporkan tidak akan diproses dan dapat membawa efek buruk terhadap diri pelapor atau pengadu. Apabila tindakan anggota yang diadukan diduga merupakan tindak pidana, maka yang digunakan adalah hukum acara pidana yang juga digunakan untuk menangani dugaan tindak pidana yang dilakukan oleh masyarakat umum. Hal tersebut membawa konsekuensi berlarutnya proses yang seharusnya dilakukan dengan cepat apalagi 
mengingat peran anggota Polri yang merupakan aparat penegak hukum.

Kekurangpahaman masyarakat dengan mekanisme Dumas yang ada, bertambah semakin kompleks dengan adanya faktor trauma dan perasaan tertekan yang dialami oleh masyarakat pasca pengalaman buruk yang dialaminya dengan oknum polisi membuat masyarakat seberusaha mungkin meminimalisir kontak atau hubungan apapun dengan polisi (Smith, 2009). Oleh karena itu butuh kepercayaan dan keyakinan dari masyarakat terhadap pelayanan Dumas.

Terhadap faktor-faktor sebagaimana yang telah dipaparkan, diperlukan sebuah konsep baru yang mana merupakan perbaikan dari mekanisme yang ada. Fokus konsep baru adalah melakukan perbaikan atas apa yag kurang dan mempertahankan keunggulan-keunggulan yang telah ada pada mekanisme yang sekarang dilaksanakan.

\section{Konsep Pengawasan Itwasda Polda Jateng dalam mencegah dan menindak tindakan anggota Polri di lingkungan Polda}

Penelitian ini menawarkan konsep perbaikan dari Fungsi Pengawasan Itwasda, berdasarkan faktor-faktor penghambat yang telah diuraikan di atas. Pertama, Perihal Mekanisme satu pintu. Pada mekanisme yang sekarang berlaku, dumas di lingkungan Polda dapat diterima bukan hanya oleh Itwasda, melainkan dapat pula diterima oleh
Bidpropam, Ditreskrimum, Ditreskrimsus, atau Ditresnarkoba. Hal tersebut membuat jangka waktu pengaduan hingga penanganan dumas menjadi lebih lama dikarenakan adanya proses birokrasi. Serta menimbulkan kerancuan dalam penanganan karena berbeda tugas pokok dan fungsinya. Apabila disosialisasikan kepada masyarakat tentang adanya mekanisme satu pintu, maka masyarakat sendiri tidak akan kebingungan, dan dapat dengan mudah memahami kemana mereka harus melapor atau mengadu apabila melihat atau mengalami kerugian atas tindakan anggota yang tidak sesuai KEPP dan/atau tidak sesuai dengan peraturan perundangundangan. Telah menjadi rahasia umum bahwasanya masyarakat seringkali membiarkan atau bersikap acuh tak acuh terhadap perbuatan menyeleweng yang dilakukan anggota Polri khususnya atau pegawai negeri sipil umumnya, dikarenakan ketidaktahuan kemana mereka harus melapor. Dengan adanya penyederhanaan mekanisme, diharapkan peran serta masyarakat dapat meningkat dan dapat membawa peningkatan integritas anggota serta peningkatan kepercayaan masyarakat kepada institusi.

Kedua, peneltian ini menawarkan gagasan mengenai Penggabungan Penyidik dari Ditreskrimum, Ditreskrimsus, dan Ditresnarkoba dalam Tubuh Itwasda. Sebagaimana yang terjadi pada lembaga Komisi Pemberantasan Korupsi (KPK), terdapat beberapa penyidik dari kepolisian yang 
dimasukkan dalam lembaga. Hal tersebut memiliki dampak positif terutama terkait dengan efektifitas dan efisiensi penanganan perkara. Para penyidik yang dimasukkan dalam tubuh Itwasda nantinya khusus menangani perkara anggota Polri yang diduga melakukan tindak pidana. Diharapkan para penyidik ini nantinya dapat lebih fokus dan lebih cepat melakukan penanganan terhadap dumas yang diadukan. Selain itu, dengan adanya penggabungan yang dapat bersifat sementara ini, maka proses lapor-melapor terkait sejauh mana proses penanganan menjadi lebih sederhana. Itwasda dapat lebih responsif, bukan hanya terkait dengan pelaporan sejauh mana penanganan dilakukan, melainkan juga dapat mengurangi waktu proses penanganan. Hal ini juga dapat memangkas waktu proses perkoordinasian antar satfung yang terkait.

Ketiga, menurut perlu adanya Komputerisasi Dumas. Kecuali hal-hal yang tidak dapat dikomputerisasi seperti pengumpulan bukti-bukti, penanganan dumas dapat dilakukan komputerisasi. Komputerisasi ini khususnya untuk memberikan kemudahan bagi pengadu untuk mengetahui sejauh mana penanganan terhadap aduannya telah dilaksanakan.

Keempat, berdasarkan penelitian dan pengamatan yang dilakukan, maka perlu Hukum Acara Pidana Khusus untuk Aparat Penegak Hukum. Hukum acara pidana yang sekarang berlaku untuk anggota Polri yang merupakan aparat penegak hukum adalah sama dengan hukum acara pidana yang digunakan atau dikenakan kepada masyarakat umum. Penggunaan hukum acara pidana tersebut memberi pengaruh besar terutama terkait dengan jangka waktu yang dibutuhkan untuk penanganan hingga penyelesaian dumas terkait dengan tindak pidana yang dilakukan oleh anggota. Butuh waktu 3 hingga 8 bulan dalam penyelesaian dumas terkait dengan tindak pidana yang diduga dilakukan oleh anggota. Jangka waktu tersebut bisa menjadi lebih lama apabila dilakukan banding, kasasi, dan/atau peninjauan kembali. Hukum acara pidana khusus diperlukan guna mempersingkat waktu yang dapat ditempuh dalam penyelesaian kasus dimana aparat penegak hukum merupakan terdakwanya. Hal ini diperlukan terutama untuk mengatasi tingkat kepercayaan yang rendah dari masyarakat terhadap aparat penegak hukum, juga sebagai bahan kontrol bagi aparat penegak hukum untuk bertindak sesuai dengan peraturan perundang-undangan.

Yang Kelima, perlu adanya Perluasan Kewenangan Itwasda dalam Memutuskan Tindak Lanjut Penanganan Dumasan. Itwasda tidak memiliki kewenangan untuk memutuskan suatu penanganan dumas, Itwasda hanya sebatas memberikan datadata atau bukti terkait mengenai indikasi terjadinya pelanggaran atau tindakan indisipliner anggota Polri yang kemudian diklarifikasi ke pengadu dan yang teradu. Jika benar terdapat pelanggaran maka satfung yang berwenang yaitu Bidpropam 
Law Reform

Volume 15, Nomor 1, Tahun 2019
Program Studi Magister Ilmu Hukum Fakultas Hukum Universitas Diponegoro (pelanggaran disiplin \& kode etik profesi) dan Ditkrimum/Ditkrimsus/Ditnarkoba (pidana) yang akan menjatuhkan sanksi. Dengan demikian kewenangan itwasda sebenarnya terbatas padahal tombak utama dalam penerimaan dan penanganan pengaduan adalah Itwasda sehingga seharusnya Itwasda diberikan kewenangan untuk memberikan rekomendasi, dimana rekomendasi harus dilaksanakan dan merupakan dasar penjatuhan sanksi yang sifatnya mutlak. Jika ditinjau dari perspektif hukum progresif dimana hukum progresif bermakna hukum yang peduli terhadap kemanusiaan sehingga bukan sebatas dogmatis belaka, dimana secara spesifik hukum progresif antara lain bisa disebut sebagai hukum yang pro rakyat dan hukum yang berkeadilan maka rekomendasi dari Itwasda berupa penelusuran lebih jauh mengenai kondisi psikologis anggota yang terbukti melakukan tindakan indisipliner, mengadakan konseling psikologis bagi yang terbukti terdapat indikasi pelanggaran yang berulang, mencari tahu penyebab yang bersangkutan melakukan pelanggaran, dan lebih dalam menggali keadaan atau lingkungan kerja di sekitar anggota tersebut. Penggalian yang lebih dalam ini dapat meninjau aspek sosial, ekonomi, dan bahkan mentalitas seorang anggota. Hasil yang diperoleh dari penelusuran ini dapat dijadikan sebagai bahan masukan untuk proses rekruitmen Polri berikutnya oleh Biro Sumber Daya Manusia Polda Jawa Tengah yang pada akhirnya dapat melakukan pencegahan dini anggota Polri melakukan tindakan indisipliner.

Konsep pengawasan Itwasda Polda Jateng dalam mencegah dan menindak tindakan anggota Polri di lingkungan Polda mengupayakan penegakan hukum progresif. Menurut Lawrence Friedman (Friedman, 1975) yang berkeadilan substansif dalam sebuah 'terobosan hukum' yang pelaksanaannya dilatarbelakangi pada keinginan menghindari efek negatif terhadap ketidakefektifan sistem peradilan pidana dalam mengakomodir perkara-perkara pidana agar tidak diteruskan proses penegakan hukum melalui peradilan. Sehingga pada tataran implementasinya, kerap kali dikategorikan sebagai bentuk discretion atau 'diskresi', walaupun sebenarnya terdapat perbedaan yang signifikan. Dalam praktik penanganan perkara pidana pada tingkat Kepolisian, pelaksanaan penegakan hukum progresif masih mempedomani tujuan dari diskresi, yaitu untuk mendapatkan cara menangani perkara pidana ringan di luar pengadilan atau sistem peradilan yang formal. Konsep hukum ini juga diterapkan untuk meningkatkan Crime Clearance melalui penyelesaian perkara pidana ringan yang bermuara pada 'win-win solution'. Artinya, kedua belah pihak telah memperoleh keadilan tanpa harus melewati serangkaian prosesi beracara hingga ke tingkat pengadilan. Dengan hal ini diharapkan dalam penanganan perkara yang dilakukan oleh penyidik Kepolisian dapat berpihak kepada kepentingan 
masyarakat dan adanya kepastian hukum dalam penegakan hukum.

Penegakan hukum progresif tidak sama dengan adagium hukum yang berbunyi "la bouche de la loi". Artinya penegakan hukum progresif tidaklah semudah seperti memencet tombol kemudian langsung membuahkan hasil yang pasti seperti halnya sistem mekanisasi. Penegakan hukum progresif adalah sesuatu yang membutuhkan compassion, empathy, commitment dan dare atau courage. Faktor keberanian inilah yang memegang peranan penting untuk dapat menggerakkan penegakan hukum progresif (Nugroho, 2014). Selain itu, hukum progresif juga harus disertai kreativitas dalam kontek penegakan hukum. Maksud dari kreativitas ini adalah bagaimana Polisi sebagai penegak hukum haruslah mampu mengatasi ketertinggalan hukum, mengatasi ketimpangan hukum dan mampu menciptakan terobosanterobosan hukum yang belum pernah ada yang mampu mewujudkan tujuan kemanusiaan melalui bekerjanya hukum(Ravena, 2007).

Progresifitas Polisi diharapkan mampu memulihkan citra polisi yang mulai menurun di mata masyarakat yang memunculkan banyak kritik, keluhan dan ketidakpuasan dari masyarakat. Progresifitas sangat diperlukan dikarenakan Polisi dalam melakukan penegakan hukum haruslah sinergi dengan kultur masyarakat, sehingga kinerja polisi dapat menuju ke kehidupan hukum yang diharapkan oleh masyarakat (Nawawi, 2010). Sebab sejatinya, penegakan hukum yang dilakukan oleh Polisi tidak boleh mengabaikan kepentingan hukum dan kepentingan akan kepatuhan hukum masyarakat (Ridwan, 2012). Hal ini dikarenakan hukum merupakan pencerminan dari masyarakatnya, sehingga konsep kultur hukum menjadi sangat penting untuk dipertimbangkan dalam penegakan hukum (Mukhidin, 2014).

Adapun pengawasan Itwasda Polda Jateng dalam mencegah dan menindak tindakan anggota Polri di lingkungan Polda bertujuan agar dapat ditemukannya konsep alternatif penegakan hukum untuk menyelesaian suatu perkara pidana diluar peradilan dalam rangka memberikan kepastian hukum. Itwasda Polda Jateng mengkaji data-data penanganan dari laporan masyarakat dan melakukan penyidikan kepada petugas kepolisian yang dilaporkan masyarakat atau melakukan tindakan indisipliner dengan mencari solusi alternatif penyelesaian perkara pidana terutama yang merupakan delik murni dengan kerugian kecil, tindak pidana ringan dan apabila ada penyelesaian diantara kedua pihak yang berperkara dengan melalui penyelesaian secara perdamaian dan ada kepastian hukum terhadap penegakan hukum dengan penghentian penyidikan. Itwasda juga agar dapat memberikan saran untuk melakukan counceling psikologi kepada anggota yang melakukan tindakan indisipliner. 


\section{SIMPULAN}

Itwasda mampu untuk melaksanakan tugas dan fungsinya dalam rangka pengawasan terhadap tindakan anggota. Itwasda yang memiliki peran sebagai koordinator dari segala penanganan dumas, telah menjalankan perannya dengan baik, meskipun terdapat masalah utama yakni jangka waktu penyelesaian dumas yang tergolong tidak menentu dan lama.

Faktor yang mempengaruhi pelaksanaan fungsi pengawasan dibagi menjadi dua, yakni faktor pendorong dan faktor penghambat. Faktor pendorong terdiri dari Koordinasi/kerjasama yang baik antar satuan fungsi, Kewenangan Itwasda yang terbatas dalam penanganan dumas dan Dukungan masyarakat atas eksistensi Itwasda. Sementara itu, faktor penghambat terdiri dari: Mekanisme yang tidak satu pintu, Kesalahan birokrasi dari satuan fungsi terkait, Jumlah anggota subbag dumasan kurang jika dibandingkan dengan keseluruhan tugas yang diemban, Ketidaknyamanan penanganan dan penindakan terhadap rekan sejawat, Masyarakat yang kurang memahami mekanisme dumas dan Berbelitnya proses penyelidikan hingga penjatuhan putusan.

Atas deskripsi yang telah dipaparkan pada bagian-bagian sebelumnya, penulis memiliki sebuah konsep untuk perbaikan pelaksanaan fungsi pengawasan terhadap anggota Polri di lingkungan Polda, yang mana konsep tersebut bukan hanya terkait dengan Itwasda saja, namun juga menyangkut satuan fungsi lain yang terkait. Ide utama konsep mekanisme tersebut antara lain dengan adanya mekanisme satu pintu (pelayanan terpadu), Penggabungan penyidik dari Ditreskrimum, Ditreskrimsus, dan Ditresnarkoba dalam tubuh Itwasda, Komputerisasi dumas, dan Hukum acara pidana khusus bagi aparat penegak hukum.

Penanganan dumas yang dilaksanakan oleh Itwasda telah dilakukan secara baik, namun demikian perlu perluasan kewenangan Itwasda dalam pelaksanaan fungsi pengawasan terhadap tindakan anggota yang disangka atau diduga melanggar KEPP dan/atau hukum. Perluasan kewenangan ini utamanya terkait dengan peran Itwasda yang sekarang berperan sebagai 'tukang foto'-karena tugasnya hanya memonitor, menjadi salah satu mesin dalam pengkajian atas dumas. Selain itu, perlu untuk dibuat hukum acara pidana khusus untuk tersangka/terdakwa yang merupakan aparat penegak hukum sehingga jangka waktu penanganan bisa lebih cepat.

\section{DAFTAR PUSTAKA}

\section{BUKU}

Friedman, Lawrence M. (1975). The Legal System : A Social Science Perspective. New York: Russel Sage Foundation.

Kunarto. (1997). Etika Kepolisian. Jakarta: Cipta Manunggal. 
Rahardjo, S. (2002). Polisi Sipil dalam Perubahan Sosial di Indonesia (H. Asy'ari, ed.). Jakarta: Penerbit Buku Kompas.

Sadjijono. (2006). Hukum Kepolisian (Mutrofin, ed.).

Yogy: LaksBang PRESSindo.

Syamsudin, M. (2007). Operasionalisasi Penelitian

Hukum. Jakarta: Raja Grafindo Persada.

\section{JURNAL}

Brandl, Steven G., Stroshine, Megan S., \& Frank, James. (2001). Who are the complaint-prone officers?: An examination of the relationship between police officers' attributes, arrest activity, assignment, and citizens' complaints about excessive force. Journal of Criminal J ustice, Vol.29, (No.6), pp.521-529.

Hassel, Kimberly D., \& Archbold, Carol A. (2013). Widening the scope on complaints of police misconduct. Policing: An International J ournal of Police Strategies and Management, Vol.33,(No.3), pp.473-489.

Lersch, Kim Michelle., \& Mieczkowski, Tom. (1996). Who are the problem-prone officers? An analysis of citizen complaints. American J ournal of Police, Vol.15, (No.3), pp.23-44. https://doi.org/https://doi.org/10.1108/07358549 610129613

Mukhidin. (2014). Hukum Progresif Sebagai Solusi Hukum yang Mensejahterahkan Rakyat. J urnal Pembaharuan Hukum, Vol.1,(No.3), pp.267-
286.

Mustansyr, R. (2008). Landasan Filosofis, Mazhab Hukum Progresif: Tinjauan Filsafat IImu. J urnal Filsafat, Vol.18,(No.1), pp.17-18.

Nawawi, K. (2010). Progresifitas Polisi Menuju Polisi Profesional. INOVATIF Jurnal Ilmu Hukum, Vol.2, (No.3), pp.55-69.

Nugroho, W. (2014). Rule Breaking Dan Integritas Penegak Hukum Progresif Dalam Pemberantasan Korupsi Pejabat Daerah : Kajian Putusan Mahkamah Konstitusi Nomor 73/PUU-IX/2011. Yudisial, Vol.7, (No.1), pp.7087.

Rahardjo, S. (2005). Hukum Progresif, Hukum yang Membebaskan. Jurnal Hukum Progresif, Vol.1, (No.1), pp.1-24.

Ravena, D. (2007). Mencandra Hukum Progresif dan Peran Penegakan Hukum di Indonesia. Syiar Hukum, Vol.9, (No.3), pp.190-201.

Ridwan. (2012). Menciptakan Keadilan Dengan Penerapan Hukum Progresif Melalui Pendekatan IImu Ketuhanan. Kanun J urnal IImu Hukum, Vol.14, (No.2), pp.249-262.

Seron, Carroll., Pereira, Joseph., \& Kovath, Jean. (2004). Judging Police Misconduct: "StreetLevel" versus Professional Policing. Law and Society Review, Vol.38, (No.4), pp.665-710.

Smith, G. (2009). Why Don't More People Complain against the Police? European Journal of Criminology, Vol.6, (No.3), pp.249-266. 
Widiawati, N. (2011). Pencatatan Pengaduan Masyarakat Tentang Penyimpangan Polri Sesuai Konsep FADO. Jurnal Kriminologi Indonesia, Vol.7, (No.1), pp.1-19.

\section{SUMBER ONLINE}

Kencana, D. (2015). 107 Anggota Polda Jateng Lakukan Pelanggaran Etik. Metrotvnews.Com. Retrieved from http://jateng.metrotvnews.com/ peristiwa/GNGED6zk-107-anggota-poldajateng-lakukan-pelanggaran-etik Kumoro, T. (2018). Terlibat Asusila Hingga Narkoba, 15 Anggota Polda Jateng Dipecat. J awapos.Com. Retrieved from https://www.jawapos.com/jpgtoday/31/12/2018/terlibat-asusila-hingganarkoba-15-anggota-polda-jateng-dipecat/ 